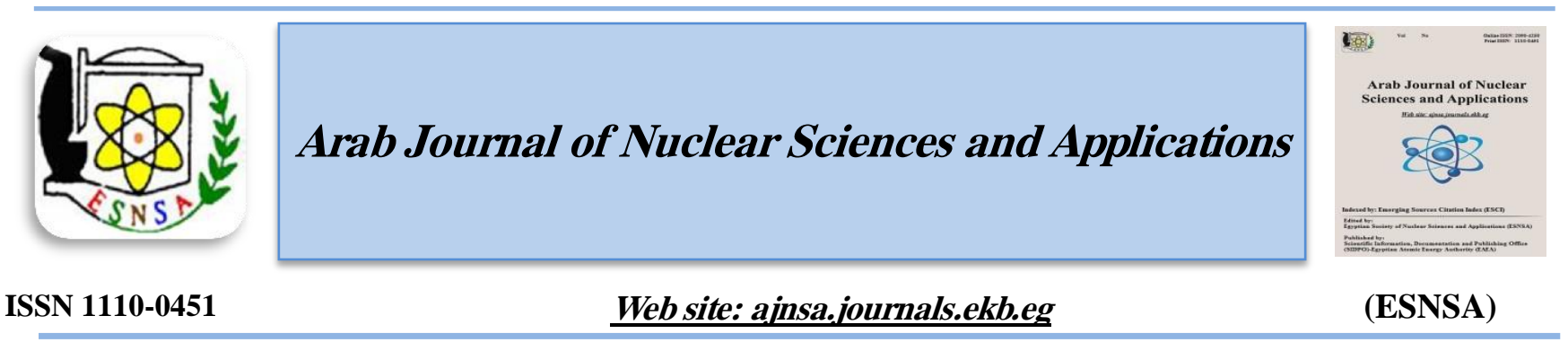

\title{
Uranium Partitioning During Water Treatment Processes
}

\author{
Ashraf E.M. Khater \\ Nuclear Safeguards and Physical Protection Department, Nuclear and Radiological Regulatory Authority, Cairo, \\ Egypt
}

\begin{abstract}
Received $29^{\text {th }}$ Apr. 2019 Some of non-renewable water resources such as deep groundwater aquifers were explored extensively Accepted $21^{\text {th }}$ May 2019 for the use as drinking water. Water treatment plants (WTPs) were established to fulfill the standards of drinking water quality. The study of the chemical behavior of uranium $(U)$ in groundwater treatment process is the main aim of this work that will shed more light on $U$ removal efficiency during water treatment processes. Samples represent various treatment processes such as sand filtration and reverse osmosis were collected. Uranium and other elements (e.g. Ba, $\mathrm{Ca}, \mathrm{Fe}, \mathrm{K}, \mathrm{Mg}, \mathrm{Na}$ and $\mathrm{Sr}$ ) concentrations were measured using ICP-MS that shows a wide range of variation. In addition, some physicochemical parameters -such as $\mathrm{pH}$, electric conductivity- $\mathrm{EC}$, major cations $\left(\mathrm{Ca}^{2+}, \mathrm{Mg}^{2+}, \mathrm{Na}^{+}\right.$and $\left.\mathrm{K}^{+}\right)$and major anions $\left(\mathrm{CO}_{3}{ }^{2-}, \mathrm{HCO3}^{-}, \mathrm{Cl}^{-}\right.$and $\left.\mathrm{SO}_{4}{ }^{2-}\right)$ were measured. The removal efficiency of $\mathrm{U}$ was about $99 \%$ by reverse osmosis (RO) process that leads to increasing the $U$ concentration $(293 \%)$ in $R O$ reject and consequently in evaporation bond. The concentration of $U$ and other toxic elements in evaporation bond's water could be a serious potential source of environmental contamination due to their continuous increase with water volume reduction.
\end{abstract}

Keyword: Uranium/ Water treatment plant/ ICP-MS/ Removal efficiency

\section{Introduction}

Drinking water resources are scarce in many places around the world especially in arid and semiarid regions [1]. In some regions to cover the drinking water demands, sea and underground water desalination were an option that required to treat the water from different resources to fulfill the essential standards for drinking water quality. The source water quality affect both the applied techniques as well the cost of water treatment [2]. water treatment plants (WTPs) were built-up to reduce some elemental concentrations and to modify the various physicochemical parameters that make the water quality complies with the national and/or international standards.
Generally, the natural water resources contain different elemental concentrations and physicochemical parameters that characterize the water itself as well as its source. Underground water resources have various parameters that fingerprint the water chemistry and the geochemical features of the aquifer bedrocks as well as the water-rocks interactions [3-5].

Some underground resources could contain relatively high concentrations of toxic elements and even essential nutrient elements with a higher concentration than that of drinking water quality guidelines [6]. There are many national and some international guidelines for drinking water quality [7-10]. These guidelines covered various aspects of

Corresponding author: khater ashraf@yahoo.com

DOI: 10.21608/ajnsa.2019.12389.1212 
water properties. There are many published works that deal with water quality and guidelines [11-15]. The occurrence of natural radio-nuclides (e.g. ${ }^{238} \mathrm{U}$, ${ }^{226} \mathrm{Ra},{ }^{228} \mathrm{Ra},{ }^{40} \mathrm{~K}$ and others) in underground water is mainly due to their leaching from the bed-rocks. The concentration of uranium in water depends on several factors. These include the uranium concentration in the aquifer rock, the partial pressure of carbon dioxide, and the presence of oxygen and complexing agents. Different parameters of water determine its capacity to dissolve, transfer or participate elements that include its $\mathrm{pH}$ value, temperature, redox potential, concentration and properties of dissolved salts, flow rate and residence time [16-17].

Uranium (U) is a natural element that could exist in different concentrations and chemical forms that imposed a serious health risk. Health effects and risk of $U$ can be divided into radiological risk of $U$ radio-nuclides and chemical risk due to its chemotoxicity as a toxic heavy metal. US Environmental Protection Agency (EPA) has classified $U$ as a confirmed human carcinogen (group A). Environmental Protection Agency (EPA) has suggested that only zero tolerance is a safe acceptable limit for the carcinogenic risk from uranium and finalized realistic regulation levels as maximum contaminant level (MCL) of $30 \mu \mathrm{g} / \mathrm{L}$. Standardization and Metrology Organization for the Gulf Cooperation Council Countries set MCL of $15 \mu \mathrm{g} / \mathrm{L}$. Canada regulations proposed interim maximum acceptable level (IMAC) of $20 \mu \mathrm{g} / \mathrm{L}$. While the World Health Organization (WHO) strictly recommended a reference level of $2 \mu \mathrm{g} / \mathrm{L}$ in 1998 that have been changed to 15 and $30 \mu \mathrm{g} / \mathrm{L}$ in 2004 and 2011, respectively) [8, 18-19]. Many publications provided studies on the concentration of uranium and natural radio-nuclides in drinking water [9, 16-17, 20-26], uranium removal from drinking water [27-29] and radiological dose and risk assessment [19, 30-34].

The aim of this work is to evaluate the removal efficiency of uranium by different processes in WTP and its relation to some physicochemical parameters of water samples.

\section{Experimental Work}

The WTP is located in Hail district, Northern part of Saudi Arabia and produces $10^{5} \mathrm{~m}^{3} /$ day. The water supply was brought to WPT from 18 deep (500-600 m depth) wells located in a nearby circular of $10 \mathrm{~km}^{2}$ area. The main treatment processes are shown in Figure (1) which included cooling and aeration, coagulation-flocculation and sand filtration, reverse osmosis, and chlorination. Since the raw water had been pumped from different wells, it was first gathered in mixing tank then further pumped up for cooling and aeration. The pumped water was cooled down and its gaseous contents were expelled to reduce the potential health risk of radioactive radon $\left({ }^{222} \mathrm{Rn}\right)$ gas. Then, it was pumped through sand filters composed of sand layers of varying grain sizes to remove suspended solid and colloidal material. Moreover, the different oxides especially that of iron and manganese were formed in the last two stages (aeration and partially in sand filter) that play an essential role in co-precipitation processes for some elements such as radium, which was removed by sand filters $[17,26]$. The reverse osmosis process was the final phase before mixing and chlorination. In the mixing process, the mixing ratio of reverse osmosis permit to sand filter output water was $3: 1$ to enhance the minerals content to the acceptable water quality standards [26].

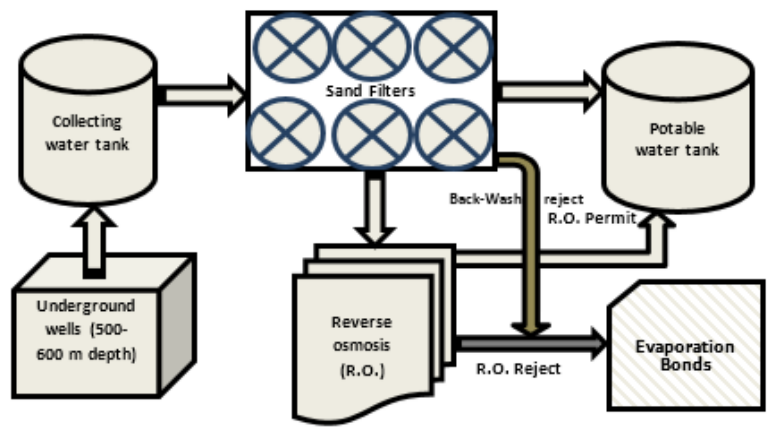

Fig. (1): The flowchart of the different processes of water treatment plant (WTP)

Eight water samples were collected from the WTP that represent different water treatment processes (input, sand filter, sludge tank, reverse osmosis, output water and evaporation ponds). Water samples were collected in $5 \mathrm{~L}$ capacity polyethylene containers that were kept in a dark place for preservation. Uranium and other elements (e.g. $\mathrm{Ba}, \mathrm{Ca}, \mathrm{Fe}, \mathrm{K}, \mathrm{Mg}, \mathrm{Na}$ and $\mathrm{Sr}$ ) concentrations were measured using PerkinElmer model ELAN9000 ICP-MS. Water samples were analyzed for different physicochemical parameters such as $\mathrm{pH}$, EC (electric conductivity, dS.cm ${ }^{-1}$ ), major cations $\left(\mathrm{Ca}^{2+}, \mathrm{Mg}^{2+}, \mathrm{Na}^{+}\right.$and $\left.\mathrm{K}^{+}\right)$and major anions $\left(\mathrm{CO}_{3}{ }^{2-}\right.$, $\mathrm{HCO}_{3}, \mathrm{Cl}^{-}$and $\mathrm{SO}_{4}{ }^{2-}$ ) were determine using standard procedures [35]. The removal efficiency $(\Delta \%)$ of uranium and other elements in water 
samples was calculated using the following equation:

$\Delta \%=\left(\mathrm{C}-\mathrm{C}_{0}\right) \times 100 / \mathrm{C}_{0}$

Where: $\mathrm{C}_{0}$; uranium concentration in input water $\mathrm{C}$; uranium concentration in the sample

Negative and positive percentages mean that uranium was removed and concentrated in the treatment process, respectively [28].

\section{Results and Discussions}

The elemental and radioactivity concentration of $\mathrm{U}$ $(1 \mu \mathrm{g} / \mathrm{L})$ and ${ }^{238} \mathrm{U}(\mathrm{mBq} / \mathrm{L})$, respectively $(1 \mu \mathrm{g} / \mathrm{L}=$ $\left.12.35 \mathrm{mBq}\left({ }^{238} \mathrm{U}\right) / \mathrm{L}\right)$, removal efficiency $(\Delta \%)$, and equation (1), were given in Table (1) and shown in Figure (2). The results indicate that $\mathrm{U}$ concentrations varied widely in the collected samples due to either its removal or enhancement where different physical as well as chemical processes were involved. According to US-EPA, U concentration could be reduced using different removal techniques such as coagulation/filtration, lime softening, anion exchange, activated alumina and membrane processes with efficiencies ranged from $80 \%$ to $99 \%$ [36-38]. The concentration of $\mathrm{U}$ remained nearly constant before RO.

The $\mathrm{RO}$ process nearly removed all $\mathrm{U}$ with a removal efficiency of about $99 \%$ that led to increasing $\mathrm{U}$ in the $\mathrm{RO}$ reject water by a factor of about $300 \%$. Huikuri et al [29] studied the effectiveness of commercial reverse osmosis equipment for simultaneous removal of some radio-nuclides and dissolved salts from water. Reverse osmosis is one of the few effective techniques that can simultaneously remove U, Ra, $\mathrm{Pb}$, Po and other dissolved salts in water that leads to almost completely demineralized water $[29,36]$. Before the final step of treatmentchlorination, the water from sand filter was mixed with that from RO (permit) with a mixing ratio of $1: 3$, to increase the minerals content in water that leads to increasing the concentration of $\mathrm{U}$ from 0.06 to $0.17 \mu \mathrm{g} / \mathrm{L}$ and decreasing the removal efficiency from $99 \%$ to $96 \%$, respectively

Table (1): Uranium concentrations $(\mu \mathrm{g} / \mathrm{L})$ and activity concentrations $(\mathrm{mBq} / \mathrm{L})$

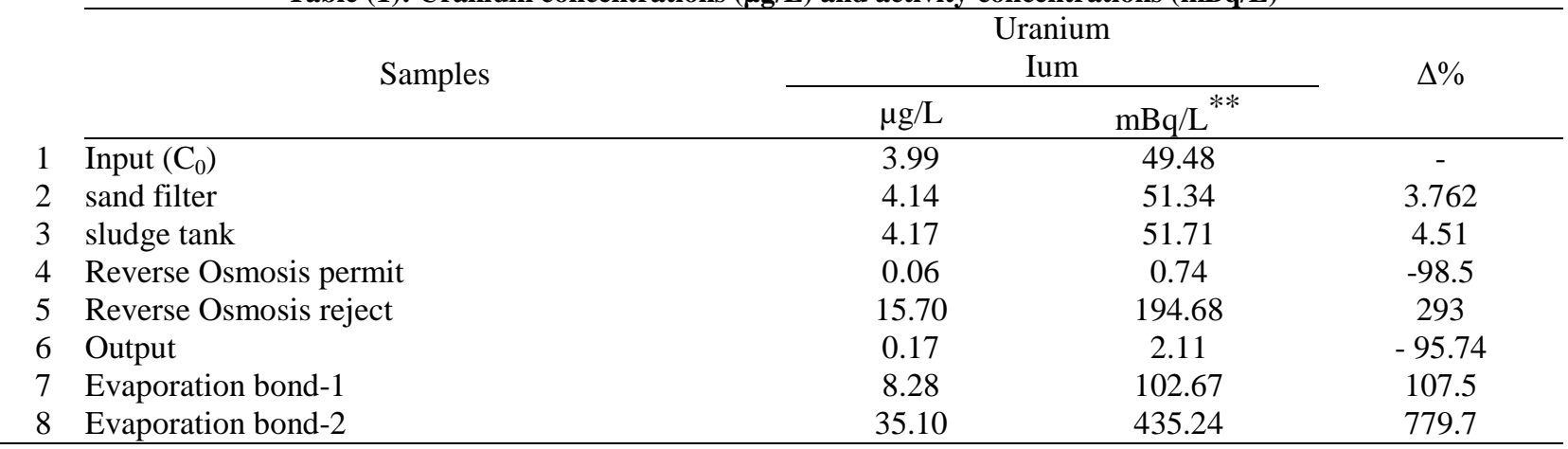

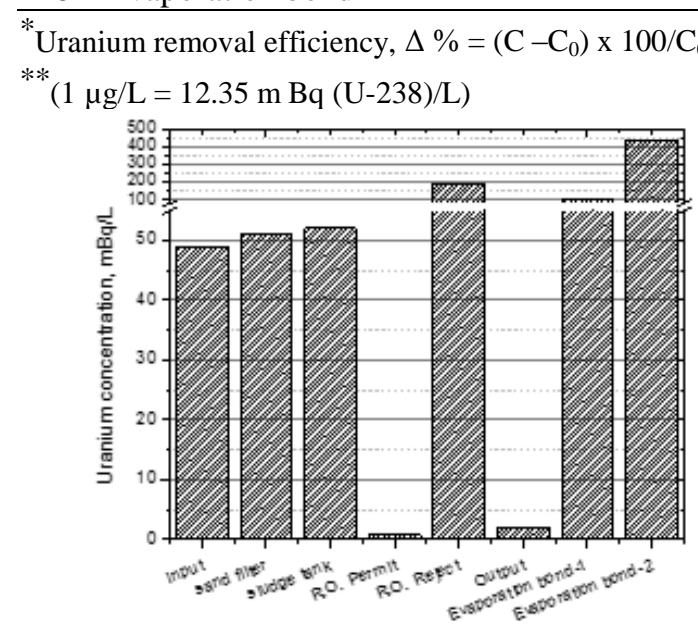

(A)

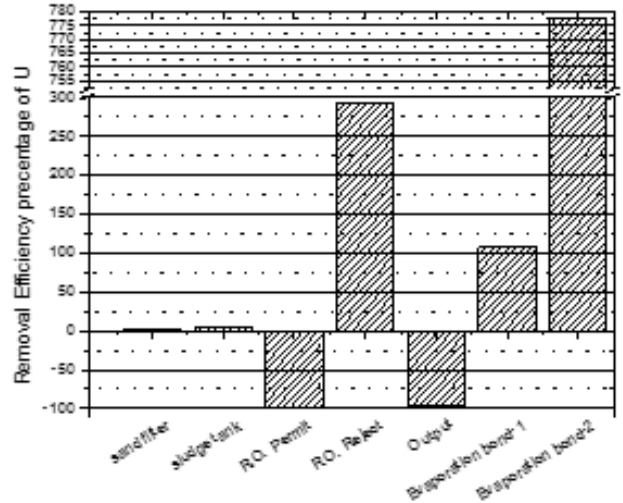

(B)

Fig. (2): (A) Uranium concentration $(\mathrm{mBq} / \mathrm{L}),(\mathrm{B})$ uranium removal efficiency percentage $(\Delta \%)$ in underground water treatment processes 
Table (2): Major ions in water samples

\begin{tabular}{|c|c|c|c|c|c|c|c|c|c|c|c|}
\hline \multirow[t]{2}{*}{ Ser. } & \multirow[t]{2}{*}{ Water sample } & \multirow[t]{2}{*}{$\mathrm{pH}$} & \multirow{2}{*}{$\begin{array}{c}\text { EC } \\
(\mathrm{dS} / \mathrm{cm})\end{array}$} & \multicolumn{4}{|c|}{ Major Cations (m Equivalent/L) } & \multicolumn{4}{|c|}{$\begin{array}{c}\text { Major Anions } \\
\text { (m Equivalent/L) }\end{array}$} \\
\hline & & & & $\mathrm{Ca}^{2+}$ & $\mathrm{Mg}^{2+}$ & $\mathrm{Na}^{+}$ & $\mathrm{K}^{+}$ & $\mathrm{CO}_{3}{ }^{2-}$ & $\mathrm{HCO}_{3}^{-}$ & $\mathrm{Cl}^{-}$ & $\mathrm{SO}_{4}{ }^{2-}$ \\
\hline 1 & Input & 8.3 & 1.2 & 6.25 & 3.71 & 4.36 & 0.15 & 1.25 & 1.5 & 7.0 & 3.43 \\
\hline 2 & Sand filter & 8.3 & 1.1 & 5.25 & 3.11 & 4.36 & 0.15 & 1.25 & 1.0 & 7.5 & 3.62 \\
\hline 3 & Sludge tank & 8.2 & 1.1 & 6.25 & 3.71 & 4.36 & 0.15 & 1.25 & 2.0 & 6.75 & 3.69 \\
\hline 4 & R.O. permit & 8.4 & 0.22 & 1 & 0.59 & 0.84 & 0.1 & 6.0 & 0.5 & - & 2.19 \\
\hline 5 & R.O. reject & 8.5 & 1.7 & 10.25 & 6.08 & 12.95 & 0.27 & 1.25 & 3 & 17.5 & 7.63 \\
\hline 6 & Output & 7.9 & 0.32 & 1.5 & 0.89 & 1.86 & 0.13 & 2.5 & 1.2 & 4.0 & 2.35 \\
\hline 7 & Evap. bond-1 & 8.3 & 5 & 26.25 & 15.56 & 25.51 & 0.63 & 1.25 & 3.0 & 36.0 & 18.45 \\
\hline 8 & Evap. bond-2 & 7.6 & 17 & 66.25 & 39.27 & 106.45 & 1.9 & 1.25 & 1.5 & 137.5 & 39.88 \\
\hline
\end{tabular}

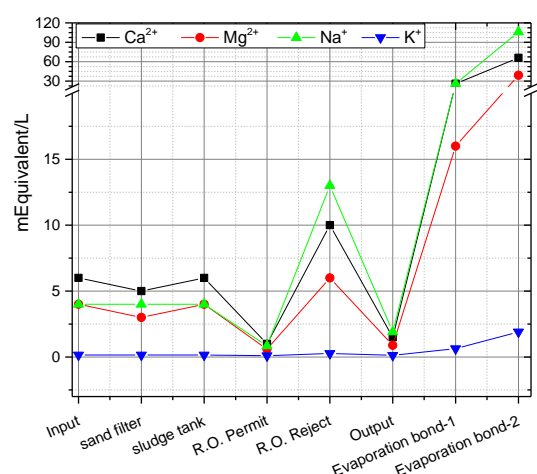

(A)

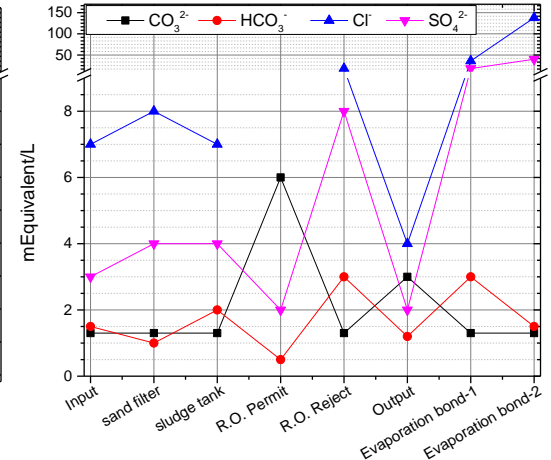

(B)

Fig. (3): The variation in Major cations (A) and major anions (B) in underground water treatment processes

The back-wash water of sand filter through sludge tank and RO reject water were sequentially pumped into 6 artificial ponds where the water left for natural solar evaporation. Uranium and other elements concentrations in evaporation ponds were continuously increased with water volume decrease due to evaporation process. The difference of $U$ concentrations increasing percentages of $108 \%$ and $778 \%$ were attributed to filling time that led to increasing $U$ and other elements in the evaporation ponds. Uranium and other elements (toxic and non-toxic) in evaporation ponds could reach very high concentrations. It is highly recommended to follow-up the quality of the water in evaporation ponds where it could be a serious source of contamination to the local environment. Evaporation ponds were lined with polyethylene sheets that raised a question; about the safety of reducing the possible potential of environmental pollution?

Physiochemical parameters [pH, EC, major cations $\left(\mathrm{Ca}^{2+}, \mathrm{Mg}^{2+}, \mathrm{Na}^{+}\right.$and $\left.\mathrm{K}^{+}\right)$and major anions $\left(\mathrm{Co}_{3}{ }^{2-}, \mathrm{HCO}_{3}^{-}, \mathrm{Cl}^{-}\right.$and $\left.\left.\mathrm{SO}_{4}{ }^{2-}\right)\right]$ of water samples were given in Table (2) and shown in Fig. (3). Values of $\mathrm{pH}$ ranged from 7.6 to 8.5 where $\mathrm{U}$ and most of heavy elements are increasingly absorbed on oxides, clays and other silicates. The absorbed fraction may be very close to $100 \%$ above $\mathrm{pH} 7$. It was reported that uranium concentrations enhanced in all water samples that has been purified within the acidic $\mathrm{pH}(<7)$ [28]. As shown in Fig. (3), RO has a very high removal efficiency, not only for $\mathrm{U}$, but also for other anions and cations that were more than $400 \%$ for $\mathrm{Ca}, \mathrm{Mg}$ and $\mathrm{Na}$, about $200 \%$ for $\mathrm{HCO}_{3}^{-}$, and about $50 \%$ for $\mathrm{K}^{+}$.

Correlation coefficients between $\mathrm{U}$ concentration and physicochemical parameters of water samples are given in Table (4) and shown in Figs. (4 and 5). Uranium correlations (correlation coefficient, $\mathrm{R})$ were strong for $\mathrm{EC}(0.93), \mathrm{Ca}(0.93), \mathrm{Mg}$ (0.93), $\mathrm{Na}(0.94), \mathrm{Cl}(0.94)$ and $\mathrm{SO}_{4}$ (0.92); good $(-0.56)$ with $\mathrm{pH}$ values and weak with $\mathrm{CO}_{3}(-0.39)$ and $\mathrm{HCO}_{3}$ (0.32). The correlation coefficient values could be interpreted based on the impacts of water treatment physicochemical treatments such as coagulation/ filtration and RO that led to water 
depletion of various salts or partially due to the chemical behavior of $\mathrm{U}$ in relation to other

elements.

Table (3): Pearson's Correlation coefficients between uranium concentration, removal efficiency $(\Delta \%)$ and physicochemical properties ( $\mathrm{pH}$, electric conductivity- EC and, major cations and anions) of water from underground water treatment plant

\begin{tabular}{cccccccccccc}
\hline & $\mathrm{U}$ & $\Delta \%$ & $\mathrm{pH}$ & $\mathrm{EC}$ & $\mathrm{Ca}$ & $\mathrm{Mg}$ & $\mathrm{Na}$ & $\mathrm{K}$ & $\mathrm{CO} 3$ & $\mathrm{HCO} 3$ & $\mathrm{Cl}$ \\
\hline $\mathrm{pH}$ & -0.56 & 0.55 & & & & & & & & & \\
$\mathrm{EC}$ & 0.93 & -0.92 & -0.72 & & & & & & & & \\
$\mathrm{Ca}$ & 0.93 & -0.93 & -0.68 & 1.0 & & & & & & & \\
$\mathrm{Mg}$ & 0.93 & -0.93 & -0.68 & 1.0 & 1 & & & & & & \\
$\mathrm{Na}$ & 0.94 & -0.94 & -0.73 & 1.0 & 0.99 & 1 & & & & & \\
$\mathrm{~K}$ & 0.93 & -0.93 & -0.73 & 1.0 & 0.99 & 1 & 1.0 & & & & \\
$\mathrm{CO} 3$ & -0.39 & 0.43 & 0.14 & -0.3 & -0.33 & -0.3 & -0.27 & -0.27 & & & \\
$\mathrm{HCO} 3$ & 0.32 & -0.31 & 0.25 & 0.1 & 0.18 & 0.2 & 0.09 & 0.11 & -0.63 & & \\
$\mathrm{Cl}$ & 0.94 & -0.94 & -0.71 & 1.0 & 0.99 & 1 & 1.0 & 1.00 & -0.25 & -0.03 & \\
$\mathrm{SO} 4$ & 0.92 & -0.92 & -0.66 & 1.0 & 1.0 & 1 & 0.98 & 0.99 & -0.31 & 0.20 & 0.98 \\
\hline
\end{tabular}
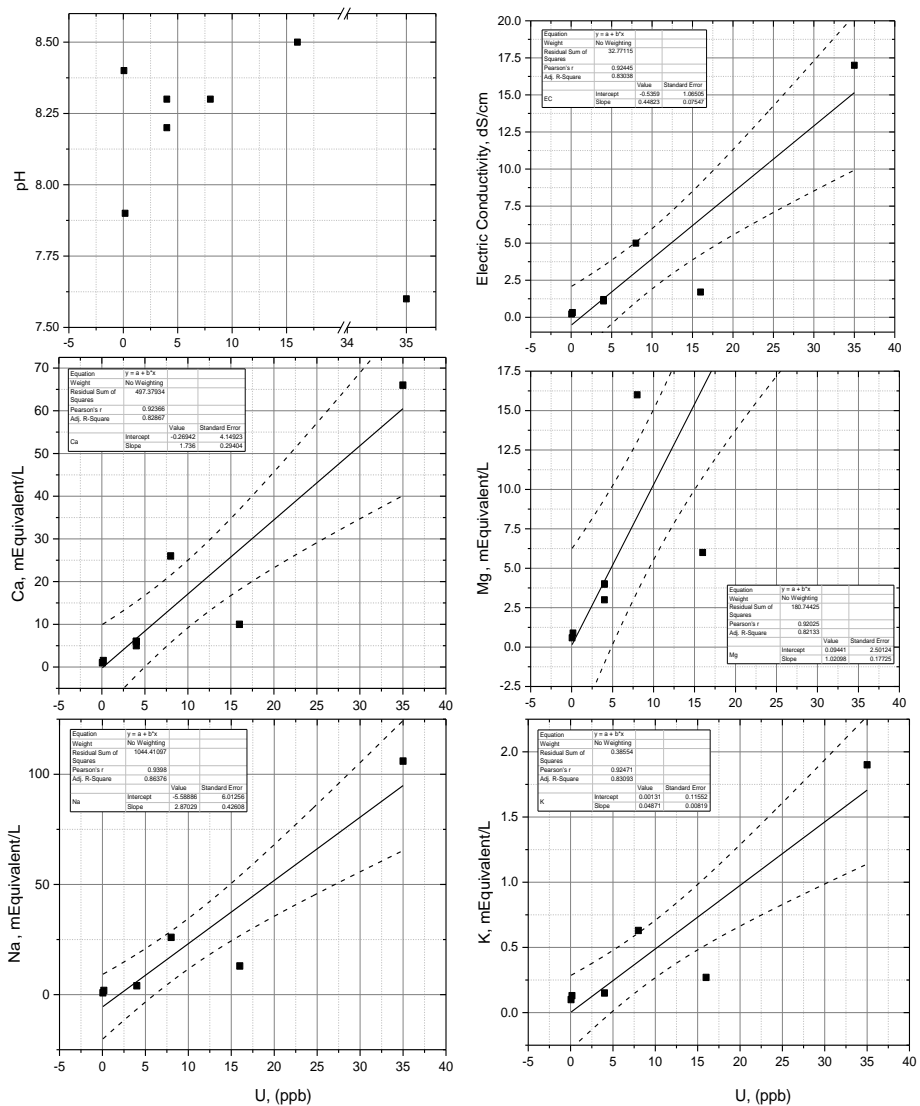

Fig. (4): The correlation pattern between $\mathrm{U}$ in $\mu \mathrm{g} / \mathrm{L}$ and $\mathrm{pH}$, electric conductivity (EC) and major cations $\left(\mathrm{Ca}^{2+}, \mathrm{Mg}^{2+}\right.$, $\mathrm{Na}^{+}$and $\mathrm{K}^{+}$) in $\mathrm{m}$ Equivalent/L 

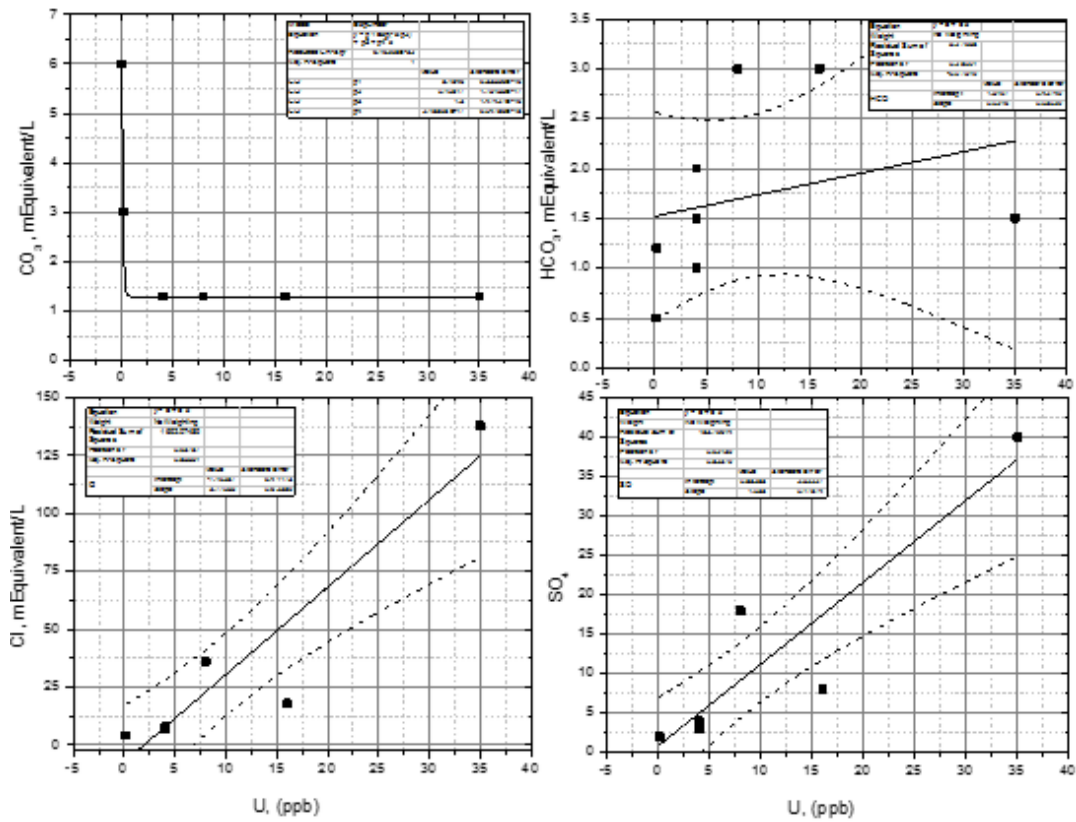

Fig. (5): The correlation pattern between $\mathrm{U}$ in $\mu \mathrm{g} / \mathrm{L}$ and major anions $\left(\mathrm{CO}_{3}{ }^{2-}, \mathrm{HCO}_{3}{ }^{-}, \mathrm{Cl}^{-}\right.$and $\left.\mathrm{SO}_{4}{ }^{2-}\right)$ in $\mathrm{m} \mathrm{Equivalent/L}$

Table (4): The concentration of barium, calcium, iron, potassium, magnesium, sodium and strontium in water samples using ICP-MS and their removal efficiency percentage $(\Delta \%) *$ in WTP processes

\begin{tabular}{|c|c|c|c|c|c|c|c|c|}
\hline & \multirow{2}{*}{ Water sample } & $\mathrm{Ba}$ & $\mathrm{Ca}$ & $\mathrm{Fe}$ & $\mathrm{K}$ & $\mathrm{Mg}$ & $\mathrm{Na}$ & $\mathrm{Sr}$ \\
\hline & & $\mu \mathrm{g} / \mathrm{L}$ & $\mathrm{mg} / \mathrm{L}$ & $\mu \mathrm{g} / \mathrm{L}$ & $\mathrm{mg} / \mathrm{L}$ & $\mathrm{mg} / \mathrm{L}$ & $\mathrm{mg} / \mathrm{L}$ & $\mathrm{mg} / \mathrm{L}$ \\
\hline 1 & Input $\left(\mathrm{C}_{0}\right)$ & 66.1 & 99.4 & 610 & 7 & 13.35 & 105 & 1.21 \\
\hline 2 & Sand filter & $\begin{array}{c}66.8 \\
(1.1)^{*}\end{array}$ & $\begin{array}{c}86.2 \\
(-13.3) \\
\end{array}$ & $\begin{array}{c}570 \\
(-6.6))\end{array}$ & $\begin{array}{c}7 \\
(0) \\
\end{array}$ & $\begin{array}{c}12.4 \\
(-7.1) \\
\end{array}$ & $\begin{array}{c}100 \\
(-4.8) \\
\end{array}$ & $\begin{array}{c}1.16 \\
(-4.1) \\
\end{array}$ \\
\hline 3 & Sludge tank & $\begin{array}{l}67.5 \\
(2.1) \\
\end{array}$ & $\begin{array}{c}97 \\
(-2.4) \\
\end{array}$ & $\begin{array}{l}610 \\
(0) \\
\end{array}$ & $\begin{array}{c}7 \\
(0) \\
\end{array}$ & $\begin{array}{c}13.35 \\
(0)\end{array}$ & $\begin{array}{c}106 \\
(1.0)\end{array}$ & $\begin{array}{c}1.21 \\
(0)\end{array}$ \\
\hline 4 & R.O. permit & $\begin{array}{c}3.51 \\
(-94.7) \\
\end{array}$ & $\begin{array}{c}6.8 \\
(-93.2) \\
\end{array}$ & $\begin{array}{c}80 \\
(-86.9) \\
\end{array}$ & $\begin{array}{c}<5 \\
(<-28.6)\end{array}$ & $\begin{array}{c}0.99 \\
(-92.6)\end{array}$ & $\begin{array}{c}26 \\
(-75.2)\end{array}$ & $\begin{array}{l}0.076 \\
(-100)\end{array}$ \\
\hline 5 & R.O. reject & $\begin{array}{c}202 \\
(206)\end{array}$ & $\begin{array}{c}278 \\
(180)\end{array}$ & $\begin{array}{l}>1000 \\
(>63.9)\end{array}$ & $\begin{array}{c}13 \\
(85.7)\end{array}$ & $\begin{array}{c}39.3 \\
(194)\end{array}$ & $\begin{array}{c}273 \\
(160)\end{array}$ & $\begin{array}{c}3.67 \\
(203)\end{array}$ \\
\hline 6 & Output & $\begin{array}{c}7.34 \\
(-88.9)\end{array}$ & $\begin{array}{c}14.2 \\
(-85.7)\end{array}$ & $\begin{array}{c}40 \\
(-93.4)\end{array}$ & $\begin{array}{c}<5 \\
(-<28.6)\end{array}$ & $\begin{array}{c}2.13 \\
(-84.0)\end{array}$ & $\begin{array}{c}50 \\
(-52.4)\end{array}$ & $\begin{array}{l}0.161 \\
(-100)\end{array}$ \\
\hline 7 & Evap. bond-1 & $\begin{array}{l}195.5 \\
(196)\end{array}$ & $\begin{array}{c}564 \\
(467)\end{array}$ & $\begin{array}{l}>1000 \\
(>63.9)\end{array}$ & $\begin{array}{c}24 \\
(243)\end{array}$ & $\begin{array}{c}86.6 \\
(549)\end{array}$ & $\begin{array}{c}568 \\
(441)\end{array}$ & $\begin{array}{c}8.12 \\
(571)\end{array}$ \\
\hline 8 & Evap. bond-2 & $\begin{array}{c}250 \\
(278)\end{array}$ & $\begin{array}{c}1330 \\
(1238)\end{array}$ & $\begin{array}{l}>1000 \\
(>63.9)\end{array}$ & $\begin{array}{c}93 \\
(1229)\end{array}$ & $\begin{array}{c}241 \\
(1705)\end{array}$ & $\begin{array}{c}2370 \\
(2157)\end{array}$ & $\begin{array}{c}23.7 \\
(1859)\end{array}$ \\
\hline
\end{tabular}

*Uranium removal efficiency, $\Delta \%=\left(\mathrm{C}-\mathrm{C}_{0}\right) \mathrm{x} 100 / \mathrm{C}_{0}$

Table (5): The quality of drinking water parameters compared to national, regional and international water quality standards

\begin{tabular}{|c|c|c|c|c|c|c|c|c|c|c|}
\hline & \multirow{2}{*}{$\mathrm{pH}$} & \multirow{2}{*}{$\begin{array}{c}\mathrm{EC} \\
(\mathrm{dS} / \mathrm{cm})\end{array}$} & \multicolumn{4}{|c|}{ Major Cations (mg/L) } & \multicolumn{4}{|c|}{ Major Anions (mg/L) } \\
\hline & & & $\mathrm{Ca}^{2+}$ & $\mathrm{Mg}^{2+}$ & $\mathrm{Na}^{+}$ & $\mathrm{K}^{+}$ & $\mathrm{CO}_{3}{ }^{2-}$ & $\mathrm{HCO}_{3}^{-}$ & $\mathrm{Cl}^{-}$ & $\mathrm{SO}_{4}{ }^{2-}$ \\
\hline Treated water & 7.9 & 0.3 & 30.1 & 10.8 & 42.8 & 5.1 & 75. & 73.2 & 141.8 & 112.9 \\
\hline SASO (2014) & $6.5-8.5$ & 2.3 & - & - & - & - & - & - & 250 & 250 \\
\hline GCCS (2014) & - & 1.6 & 200 & 150 & 20 & - & - & - & 400 & 250 \\
\hline WHO (2017) & $6.5-8.5$ & - & - & - & - & - & - & 250 & 250 & 250 \\
\hline EPA (2012) & $6.5-8.5$ & - & - & - & - & - & - & 250 & 250 & 250 \\
\hline
\end{tabular}


SASO, Saudi Arabia Standards Organization; GCCS, Gulf Council Countries Standards Organization; WHO, World Health Organization; EPA, US Environment Protection Agency

For example, uranium can form soluble complexes in most groundwaters with chloride and sulphate, and in oxidizing environment with carbonate that makes $U$ available in soluble form [17].

The concentrations of some elements (e.g. Ba, Ca, $\mathrm{Fe}, \mathrm{K}, \mathrm{Mg}, \mathrm{Na}$ and $\mathrm{Sr}$ ) and their removal efficiency percentage $(\Delta \%)$ in the WTP processes were given in Table (4). The variation of elemental concentrations within the WTP processes flow the same pattern that was previously mentioned. The concentrations enhanced as well as the removal efficiency due to RO and water evaporation. The removal efficiency of RO for the different elements ranged from 87 to $100 \%$. While, the elevation of elemental concentration relative to that of input water_ranged from about 280 to 1900 $\%$.

The quality of the produced water parameters $(\mathrm{pH}$, EC, major cations $\left(\mathrm{Ca}^{2+}, \mathrm{Mg}^{2+}, \mathrm{Na}^{+}\right.$and $\left.\mathrm{K}^{+}\right)$and major anions $\left(\mathrm{Co}^{2-}, \mathrm{HCO}_{3}{ }^{-}, \mathrm{Cl}^{-}\right.$and $\left.\mathrm{SO}_{4}{ }^{-}\right)$) were compared with the guidelines of different national (SASO), regional (GCCS-GSO) and international organizations (WHO and US-EPA) that were given in Table (5) [7-10].

The annual effective dose for adult due to ${ }^{238} \mathrm{U}$, in input (raw) and output (purified) water, intake was calculated (for annual consumption rate of 730 $\mathrm{L}$ and dose coefficient of $\left.4.5 \times 10^{-5} \mathrm{~Sv} / \mathrm{Bq}\right)$. The committed effective doses were 1.6 and 0.66 $\mu \mathrm{Sv} / \mathrm{y}$, respectively, which are below $100 \mu \mathrm{Sv} / \mathrm{y}$ the reference level of the committed effective dose recommended by the WHO [33].

\section{Conclusions}

Water treatment plants for drinking water utilize various treatment processes such as aeration, coagulation, filtration, RO, and others. The removal efficiency depends on the treatment process, water chemistry and the chemistry of the element. This study aims at studying the removal of $\mathrm{U}$ in WTP in relation to treatment processes and the chemistry of underground. There were wide variations of $U$ and other elemental concentrations in water samples after sand filtration, after RO and in evaporation bonds. The removal power of RO to remove $U$ from water could be used to decontaminate solutions in nuclear industries. The removal efficiency of $\mathrm{RO}$ of $\mathrm{U}$ and other elements was very high that led to a necessity to elevate elemental content by mixing water afer RO with water after filtration process. As the back-wash of sand filter and RO reject water was pumped to evaporation bond, the elemental concentrations were enhanced with time due to evaporation (water volume reduction) that made the water in ponds a potential source of environmental contamination.

\section{Acknowledgment}

The author acknowledges the technical support of soil department -King Saud University for water chemical analysis.

\section{References}

1. Al-Rashed, M. F., Sherif, M. M. (2000). Water resources in the GCC countries: an overview. Water resources management, 14(1), 59-75.

2. Price, J. I., Heberling, M. T. (2018). The effects of source water quality on drinking water treatment costs: a review and synthesis of empirical literature. Ecological Economics, 151, 195-209.

3. Saxena, V., Ahmed, S. (2001). Dissolution of fluoride in groundwater: a water-rock interaction study. Environmental geology, 40(9), 1084-1087.

4. Belkhiri, L., Mouni, L., Tiri, A. (2012). Water-rock interaction and geochemistry of groundwater from the Ain Azel aquifer, Algeria. Environmental geochemistry and health, 34(1), 1-13.

5. Arthur, J. D., Dabous, A. A., Cowart, J. B. (2005). Water-rock geochemical considerations for aquifer storage and recovery: Florida case studies. Developments in Water Science, 52, 327-339.

6. Abdel-Satar, A. M., Al-Khabbas, M. H., Alahmad, W. R., Yousef, W. M., Alsomadi, R. H., Iqbal, T. (2017). Quality assessment of groundwater and agricultural soil in Hail region, Saudi Arabia. The Egyptian Journal of Aquatic Research, 43(1), 55-64.

7. SASO, 2009. Saudi Arabian Standards Organization. Unbottled Drinking Water (SASO 701), Riyadh, Saudi Arabia.

8. GCCS, (2014). Gulf Cooperation Council Standards. Un-bottled drinking water standards, Standardization and Metrology Organization for the Gulf Cooperation Council Countries \#GSO 149/2014, Riyadh, Saudi Arabia.

9. WHO, 2017. World Health Organization, Guidelines for drinking water quality, $4^{\text {th }}$ edition, Geneva, Switzerland. 
10. EPA, 2012. U.S. Environmental Protection Agency. 2012 ed. of the Drinking Water Standards and Health Advisories, Washington, DC.

11. Chau, N. D., Tomaszewska, B. (2019). Mineral and Bottled Water as Natural Beverages. In Bottled and Packaged Water (pp. 1-38). Woodhead Publishing.

12. Salari, A., Khanzadi, S., Rezaei, Z. (2018). Survey of Fluoride, Chlorine, Potassium, Sodium, and Trihalomethane contents in the drinking water of five major universities in Iran. Journal of Advances in Environmental Health Research, 6(4), 202-209.

13. Labidi, S., Gharbi, S. (2018). Dose assessment to members of the pulic in Tunisia from intakes of some naturally occurring radionuclides in bottled mineral water. International Journal of Radiation Research, 16(3), 371-381.

14. Neale, P. A., Escher, B. I. (2018). In vitro bioassays to assess drinking water quality. Current Opinion in Environmental Science \& Health.

15. Khater, A. E., Al-Jaloud, A., \& El-Taher, A. (2014). Quality Level of Bottled Drinking Water Consumed in Saudi Arabia. Journal of Environmental Science and Technology, 7(2), 90.

16. Potius F W (2000) Defining a guideline for uranium. American Water Association Journal 92:18-24

17. Shabana E, Al-Hobaib A (1999) activity concentrations of natural radium, thorium and uranium isotopes in ground water of two different regions. Radiochim. Acta 87: 41-54

18. Ansoborlo, E., Lebaron-Jacobs, L., \& Prat, O. (2015). Uranium in drinking-water: A unique case of guideline value increases and discrepancies between chemical and radiochemical guidelines. Environment international, 77, 1-4.

19. Kim Y, Park H, Kim J, Park S, Cho B, sung I, Shin D (2004) Health risk assessment for uranium in Korean groundwater. Environmental Radioactivity 77: 77-85

20. Singh J, Singh H, Singh S, Bajwa B (2008) Estimation of uranium and radon concentration in some drinking water samples. Radiat. Meas. Doi: 10.1016/j.radmeas.2008.04.004

21. Godoy J, Godoy M (2006) Natural radioactivity in Brazilian groundwater. Environmental Radioactivity 85: 71-83

22. Babu M, Somashekar R, Kumar S, shivanna K, Krishnamurthy V (2008) Concentration of uranium levels in groundwater. Environmental Science and Technology 5(2): 263-266
23. International Atomic Energy agency (IAEA) (2003) Extent of environmental contamination by naturally occurring radioactive material (NORM) and technological options for mitigation. Technical Reports series No. 419: 33-49

24. Ahmed N (2004). Natural radioactivity of ground and drinking water in some areas of Upper Egypt. Turkish J. Eng. Env. Sci. 28: 345-354

25. Katsoyiannis I, Hug S, Ammann A, Zikoudi A, Hatziliontos (2007) Arsenic speciation and uranium concentrations in drinking water supply wells in Northern Greece: correlation with redox indicative parameters and implications for groundwater. Science of the Total Environment 383:128-140

26. Al-Jaseem, Q. K., Almasoud, F. I., Ababneh, A. M., Al-Hobaib, A. S. (2016). Radiological assessment of water treatment processes in a water treatment plant in Saudi Arabia: Water and sludge radium content, radon air concentrations and dose rates. Science of the Total Environment, 563, 1030-1036.

27. Gafvet T, Ellmark C, Holm E (2002) Removal of radionuclides at a waterwork. Environmental Radioactivity 63: 105-115

28. Jimenez A, Rufo D (2002) Effect of water purificiation on its radioactive content. Water Research 36: 1715-1724

29. 29 Huikuri P, Salonen L, Raff O (1998) Removal of natural radionuclides from drinking water by point of entry reverse osmosis. Desalination 119: 235-239

30. Kurttio, P., Auvinen, A., Salonen, L., Saha, H., Pekkanen, J., Mäkeläinen, I., Väisänen, S.B., Penttilä, I.M. and Komulainen, H., 2002. Renal effects of uranium in drinking water. Environmental health perspectives, 110(4), pp.337-342.

31. Orloff K, Mistry K, Charp P, Metcalf S, Marino R, Shelly T, Melaro E, Donohoe a, Jones R (2004) Human exposure to uranium in groundwater. Environmental Radioactivity 94:319-326

32. Jia G, Torri G (2007) Estimation of radiation dose to member of the public in Italy from intake of some important naturally occurring radionuclides (238U, 234U, 235U, 226Ra, 228Ra, 224Ra and 210Po) in drinking water. Appli. Radiat. Isot. 65:849-857

33. Kurttio P, Salonen L, Ilus T, Pekkanen J, Pukala E, Auvinen A (2006) Well water radioactivity and risk of cancers of the urinary organs. Environmental research 102: 333-338

34. Al-Omran M A (1987) Evaluation of some irrigation water in central region in Saudi 
Arabia. J. Coll. Agric. King Saudi University. 9: 363-369

35. EPA (Environmental Protection Agency), 2006. A Regulators' Guide to the Management of Radioactive Residuals from Drinking Water Treatment Technologies, http://www.epa.gov/radiation/docs/tenorm/816 -r-05-004.pdf
36. Esmeray, E., Aydin, M. E. (2008). Comparison of natural radioactivity removal methods for drinking water supplies: A review. Journal of International Environmental Applications \& Science, 3, 142-146.

37. Herranz M, Abelairas A, Legarda F (1997) Uranium content and associated effective doses in drinking water from Biscay (Spain). Appli. Radiat. Isot. 48 (6): 857-861 